\section{AB0553 THE NOCEBO PHENOMENON PARTLY ACCOUNTS FOR DIARRHOEA AMONG PARTICIPANTS IN THE RANDOMIZED PLACEBO-CONTROLLED TRIAL OF NINTEDANIB FOR INTERSTITIAL LUNG DISEASE ASSOCIATED WITH SYSTEMIC SCLEROSIS (SENSCIS)}

V. K. Bournia ${ }^{1}$, D. Mitsikostas ${ }^{1}$, O. Distler ${ }^{2}$, P. Sfikakis ${ }^{1} .{ }^{1}$ Medical School, National and Kapodistrian University of Athens, Joint Rheumatology Program, Athens, Greece; ${ }^{2}$ University Hospital Zurich, Department of Rheumatology, Zurich, Switzerland

Background: The nocebo phenomenon, the opposite of placebo, defined as unfavourable changes in a patient's symptoms or condition resulting from negative anticipations to treatment and possibly leading to suboptimal outcomes and non- adherence, is more frequent than previously thought in rheumatology practice[1]. The tyrosine kinase inhibitor nintedanib has shown efficacy for the treatment of systemic sclerosis (SSc)-associated interstitial lung disease in SENSCIS, a recent randomized controlled trial (RCT)[2]. Diarrhoea was the most frequently reported adverse event in SENSCIS.

Objectives: To test whether the nocebo phenomenon is involved in the prevalence of diarrhoea as an adverse event in trials with nintedanib.

Methods: We compared the incidence of diarrhoea in the placebo arm between SENSCIS and all other placebo controlled RCTs involving $>40$ SSc patients in each arm, as well as between SENSCIS and all other nintedanib RCTs published so far. We also compared the strength of the warnings for diarrhea (ie times word is mentioned and number of lines devoted to nintedanib related "diarrhoea") in the informed consent forms (ICFs) of different nintedanib RCTs Results: The mean percentage of patients reporting diarrhoea was $32 \%$ in the placebo arm and $76 \%$ in the active treatment arm in SENSCIS. These numbers are comparing to a prevalence of only $7 \%$ (range $2.3-9.1 \%$ ) and $9 \%$ (range 5.8$14 \%$ ), respectively of other RCTs in SSc (bosentan, $n=2$; macitentan, $n=2$; tocilizumab, $n=1$ ). Since the estimated point prevalence of diarrhoea in an SSc cohort similar to SENSCIS would not exceed $15 \%$ based on the literature, there was an at least 2-fold increase in the occurrence of diarrhoea in the placebo group during SENSCIS. More importantly, when looking into other nintedanib RCTs (Table 1), we found that patients reporting diarrhoea in the placebo arm were $20 \%$ and $18 \%$ in cancer and idiopathic pulmonary fibrosis (IPF) trials, respectively, which is almost half than in SENSCIS. Consistent with our hypothesis, the percentage of diarrhoea in the placebo arms of the different nintedanib RCTs increased along with the number of mentions and the number of lines devoted to "diarrhoea" in the respective ICFs.

Table 1. Percentage of patients developing diarrhoea in phase III nintedanib RCTs and diarrhoea-related warnings in ICFs

\begin{tabular}{|c|c|c|c|c|c|c|c|}
\hline $\begin{array}{l}\text { Published } \\
\text { RCT } \\
\text { (year of } \\
\text { publication) }\end{array}$ & $\begin{array}{l}\text { Treatment } \\
\text { indication }\end{array}$ & $\begin{array}{c}\text { pla- } \\
\text { cebo } \\
\text { arm, } \\
\mathrm{N}\end{array}$ & $\begin{array}{c}\text { nintedanib } \\
\text { arm, N } \\
(\mathrm{mg} / \mathrm{bid})\end{array}$ & $\begin{array}{c}\text { Adjunctive } \\
\text { treatment }\end{array}$ & $\begin{array}{c}\% \\
\text { Diarrhoea }\end{array}$ & & $\begin{array}{c}\text { Mentions } \\
\text { of 'diar- } \\
\text { rhoea'/ } \\
\text { lines } \\
\text { devoted in } \\
\text { ICF }\end{array}$ \\
\hline & & & & & Placebo & $\begin{array}{l}\text { Active } \\
\text { treat- } \\
\text { ment }\end{array}$ & \\
\hline $\begin{array}{l}\text { SENSCIS } \\
(2019)\end{array}$ & SSc-ILD & 288 & $288(150)$ & $\begin{array}{l}48 \% \text { MMF } \\
5 \% \text { MTX }\end{array}$ & 31.6 & 75.7 & $9 / 11$ \\
\hline $\begin{array}{l}\text { INBUILD } \\
(2019)\end{array}$ & $\begin{array}{l}\text { Progressive } \\
\text { Fibrosing ILD } \\
\text { including SSc- } \\
\text { ILD and other } \\
\text { CTD-ILDs }\end{array}$ & 331 & $332(150)$ & $\begin{array}{l}18 \% \geq 1 \text { from bio- } \\
\text { logics, DMARDs } \\
\text { corticoids }\end{array}$ & 23.9 & 66.9 & $8 / 10$ \\
\hline $\begin{array}{l}\text { INPULSIS1 } \\
(2014)\end{array}$ & IPF & 204 & 309 (150) & $\begin{array}{c}21 \% \\
\text { corticosteroids }\end{array}$ & 18.6 & 61.5 & $3 / 3$ \\
\hline $\begin{array}{l}\text { INPULSIS2 } \\
\text { (2014) }\end{array}$ & IPF & 219 & 329 (150) & $\begin{array}{c}21 \% \\
\text { corticosteroids }\end{array}$ & 18.3 & 63.2 & $3 / 3$ \\
\hline $\begin{array}{l}\text { LUME- } \\
\text { Lung } 1 \\
\text { (2014) }\end{array}$ & Lung cancer & 659 & $655(200)$ & docetaxel & 21.8 & 42.3 & $2 / 4$ \\
\hline $\begin{array}{l}\text { LUME- } \\
\text { Lung } 2 \\
\text { (2016) }\end{array}$ & Lung cancer & 360 & $353(200)$ & pemetrexed & 15.4 & 34.9 & $4 / 5$ \\
\hline $\begin{array}{l}\text { LUME-meso } \\
\text { phase III } \\
\text { (2019) }\end{array}$ & $\begin{array}{c}\text { Malignant } \\
\text { pleural } \\
\text { mesothelioma }\end{array}$ & 229 & $229(200)$ & $\begin{array}{l}\text { pemetrexed \& } \\
\text { cisplatin }\end{array}$ & 23.0 & 53.0 & $4 / 5$ \\
\hline
\end{tabular}

Conclusion: These results indicate that the nocebo phenomenon is partially involved in the high prevalence of diarrhoea among SSc patients participating in the SENSCIS trial. Whether patients with SSc have increased susceptibility to the nocebo phenomenon when compared to patients with IPF or cancer deserves further study.

\section{References:}

[1] KravvaritiE et al.Nat. Rev. Rheumatol.2018;14,727.

[2] Distler O et al. N. Engl. J. Med.2019;380:2518.

Disclosure of Interests: Vasiliki-Kalliopi Bournia Grant/research support from: Travel Grant from Boehringer Ingelheim, Dimos Mitsikostas: None declared, Oliver Distler Grant/research support from: Grants/Research support from Actelion, Bayer, Boehringer Ingelheim, Competitive Drug Development International Ltd. and Mitsubishi Tanabe; he also holds the issued Paten on mir-29 for the treatment of systemic sclerosis (US8247389, EP2331143). Consultant of: Consultancy fees from Actelion, Acceleron Pharma, AnaMar Bayer, Baecon Discovery, Blade Therapeutics, Boehringer, CSL Behring, Catenion, ChemomAb, Curzion Pharmaceuticals, Ergonex, Galapagos NV, GSK Glenmark Pharmaceuticals, Inventiva, Italfarmaco, iQvia, medac, Medscape, Mitsubishi Tanabe Pharma, MSD, Roche, Sanofi and UCB, Speakers bureau: Speaker fees from Actelion, Bayer, Boehringer Ingelheim, Medscape, Pfizer and Roche, Petros Sfikakis Grant/research support from: Grant/research support from Abvie, Novartis, MSD, Actelion, Amgen, Pfizer, Janssen Pharmaceutical, UCB

DOI: 10.1136/annrheumdis-2020-eular.5245

\section{AB0554 CONCORDANCE IN THE CLASSIFICATION CRITERIA IN A PATIENT COHORT WITH IDIOPATHIC INFLAMMATORY MYOPATHIES (IIM).}

F. Bozan ${ }^{1}$, S. Saavedra ${ }^{1}$, K. Vergara ${ }^{1}$, A. Goecke ${ }^{1}$, H. Gatica ${ }^{1} .{ }^{1}$ Hospital Clinico Universidad de Chile, Santiago, Chile

Background: Differents classifications criteria for IIM exist. New classification criteria are superior to previous in capturing different subgroups of IIM.

Objectives: To compare the concordance and disparity of Bohan and Peter and EULAR/ACR 2017 classification criteria at the level of diagnostic certainty, in a group of chilean patients with IIM.

Methods: 40 adults patients with IIM (27 Dermatomyositis (DM) and 13 Polimyositis (PM)), according Bohan and Peter criteria were analized. The patients were reclassified with EULAR/ACR criteria. The level of diagnostic certainty (definitive, probable and possible) was registered for both Classification Criteria. The concordance and disparity between criteria was evaluated. Concordance and disparity analysis were made considering the strict agreement between level of certainty of both criteria, using Cohen's Kappa coefficient. The analysis was done for the complete cohort and for separated groups.

Patients with discordance belonging to the same subgroup were evaluated using contingency tables. The direction of the change (gain or lost of certainty) and the relation with diagnostic subgroup was also analized. Descriptive statistics is expressed as diagnostic categories, number of patients and rates.

Results: For the complete cohort and for DM and PM groups the concordance was low. For 27 patients with DM, the observed concordance rate was $63 \%$ (16 definitives, 1 probable). The observed disparity rate was $37 \%$. The direction of the change was gain of one level of certainty in $14.5 \%$ and two levels in $22.2 \%$ of patients applying EULAR/ACR criteria compared to Bohan y Peter criteria. For 13 pacients with $\mathrm{PM}$, the observed concordance rate was $46 \%$ ( 3 definitives and 3 probables). The observed disparity rate was $54 \%$. The direction of the change was loss of certainty. The loss of certainty was one level in $85,7 \%$ (one patient change from probable to posible). Only one patiente had gain of certainty of one level (14.3\%)

Conclusion: The strict concordance between both classification criteria was low. The observed concordances were better in patients with DM that PM. The disparities involved gain of level of diagnostic certainty in DM patients, while in PM patients there was mostly lost of level of certainty.

References:

[1] Bohan A, Peter JB. Polymyositis and dermatomyositis (first of two parts). NEJM 1975;292:344-7.

[2] Bohan A, Peter JB. Polymyositis and dermatomyositis (second of two parts). NEJM 1975;292:403-7.

[3] 2017 European League Against Rheumatism/American Colllege of Rheumatology Classification Criteria for Adult and Juvenile Idiopathic Inflammatory Myopathies and Their major Subgroups. Arthritis Rheum 2017;0:1-12.

Disclosure of Interests: : None declared

DOI: 10.1136/annrheumdis-2020-eular.5662 